Article

\title{
"Trachytes" from Sardinia: Geoheritage and Current Use
}

\author{
Nicola Careddu ${ }^{1, *(1)}$ and Silvana Maria Grillo ${ }^{2}$ (D) \\ 1 Department of Civil, Environmental Engineering and Architecture (DICAAr), University of Cagliari, \\ via Marengo 2, Cagliari 09123, Italy \\ 2 Department of Chemistry and Geology (DSCG), University of Cagliari, via Trentino 51, Cagliari 09127, Italy \\ * Correspondence: ncareddu@unica.it; Tel.: +39-070-675-5561
}

Received: 11 June 2019; Accepted: 4 July 2019; Published: 6 July 2019

check for updates

\begin{abstract}
Sardinia was affected by an intense igneous activity which generated calc-alkaline products during the Oligo-Miocene period. The volcanic substance shows large variations, ranging from pyroclastic flow deposits, lava flows and domes. By composition, the deposits are all primarily dacites and rhyolites, with subordinate andesites and very scarce basalts. The rhyolite lavas show porphyritic and ash-flow tuffs. Ignimbrite structures are found in the dacitic domes and rhyolitic lavas. These rocks - commercially known as "Trachytes of Sardinia" — used to be quarried in all historical provinces, mainly in the central part of the island to be used as ornamental and building stone. They continue to be commonly used nowadays, but their use dates back to the prehistoric age. They are easily found in many nuraghi, "domus de janas", holy wells, Roman works (mosaics, paving, roads, bridges), many churches built in Sardinia and practically in all kinds of structural elements in public and private buildings, such as walls, houses, and bridges. Contrary to the granitoid rocks, whose appearance is largely influenced by the mineralogical composition, the aesthetic feature of volcanic rocks is rather affected by the widest range of colors, structure and texture, i.e., shape, size and distribution of mineral components, porphyric index, etc. "Trachyte" is quarried opencast with the "single low step" method, with descending development, with prevalent use of double-disc sawing machines. Whenever the stone deposit allows higher steps, the chain cutting machine, in combination with diamond wire, becomes the preferred extraction solution. This study aims to at look Sardinian "trachytes" from a geoheritage perspective. After a geological-petrographic framework, the paper discusses the historical uses of "trachyte" in Sardinia. The current state of the art of "trachyte" quarrying, processing and usage in the Island is also described. An analysis of the "trachyte" production has been carried out. Finally, a consideration about how to enhance geotourism in the area is suggested.
\end{abstract}

Keywords: pyroclastic rock; dimension stone; Sardinia; geoheritage; market

\section{Introduction}

"Trachyte" is the term which was used to indicate clear, rough rocks outcropping in Greece in the area of Thrace in ancient times [1]. Another etymological interpretation of the word might derive from the Greek word " $\tau \rho \rho \chi \zeta$ " which means "rough". From the petrographic point of view, trachyte is the volcanic equivalent of syenites, which are rocks formed with K-feldspar, subordinate plagioclase oligo-andesinic and mafic, such as green hornblende and biotite. Quartz is generally missing.

Differently, "Trachite auctorum" is the latin term which, in the past, indicated a multiplicity of vulcanites, from acidic to neutral (rhyolites, riodaciti, dacites and andesites), found in Central and North-Central Sardinia (Ottana, Sedilo, Allai, Fordongianus, Bosa, Ozieri, Oschiri and Osilo), southern (Serrenti) and southwestern (Sulcis) as shown in Figure 1. This term is still in use in the 
commercial field to identify this wide range of stone materials. Volcanic rocks are very different in texture (lavas, ignimbrites, pyroclastic rock welded in different ways, stagnation dome), easy to carve, they have variable porosity, and present very different color features, often characterized by a wide variable intensity: Pink, red, yellow, gray, dark gray, green, green-blue.

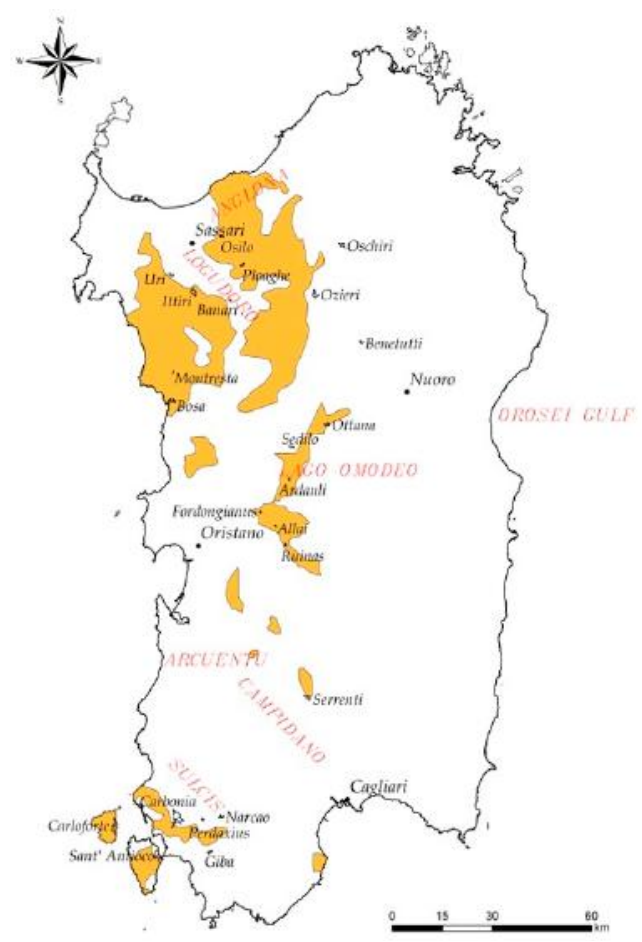

Figure 1. Lithological map of Oligo-miocenic volcanite outcrops and localities mentioned in the text (elaborated by Authors from [2]).

The aim of this study is to highlight how the "trachytes" of Sardinia can be regarded as a heritage stone resource (HSR). HSR is a natural stone, which was used in the construction of historical buildings and monuments over an extended period of time (sometimes centuries) and that should be involved in a great deal of consideration for its use in the restoration of those same historical buildings-when necessary-even when local quarries may no longer be active [3,4]. It is exactly for this reason that an international category has been created to include those global natural heritage stone resources (GHSR) that have achieved widespread utilization in human culture [5].

The present study is considered a geoheritage subtopic; geoheritage can indeed be defined as a the branch of geosciences that studies "Globally, nationally, state-wide, the regional features of geology such as its igneous, metamorphic, sedimentary, stratigraphic, structural, geochemical, mineralogic, paleontologic, geomorphic, pedologic, and hydrologic attributes at all scales, that are intrinsically important or culturally important, which offer information or insights into the formation and evolution of the Earth, or into the history of science, or which can be used for research, teaching or reference" [6]. For these reasons, heritage stone is a branch of geoheritage, which deals with the conservation of building natural stone resources that had an important role in human culture and also supports the preservation of historical quarries that once were the source of such stones.

\section{Historical and Current Uses}

These rocks have been widely used since ancient times, and can be found in numerous constructions located throughout the island. A great use of it was done during the Roman age: For example, the ancient thermal baths of Fordongianus, shown in Figure 2, which were built with squared grey boulders of "trachyte" [7], as well as the seven-arches bridge over the river Tirso, which was built with "trachyte" on top of an older bridge; Sardinian "trachyte" was also used by the Romans for the composition of 
mosaics and flooring in Nora. There is extensive footage of ancient "trachyte", used in prehistory to build defensive walls building, "Domus de Janas" (i.e., fairies' house), stone huts, nuraghi (i.e., Santu Antine, shown in Figure 3, which is one of the biggest and best preserved nuragic settlements of the island), carved vases (currently exhibited at the local Sardinian museums), mostly dating back to what is generally referred to as the "cultura di Ozieri" (middle Neolithic), etc.

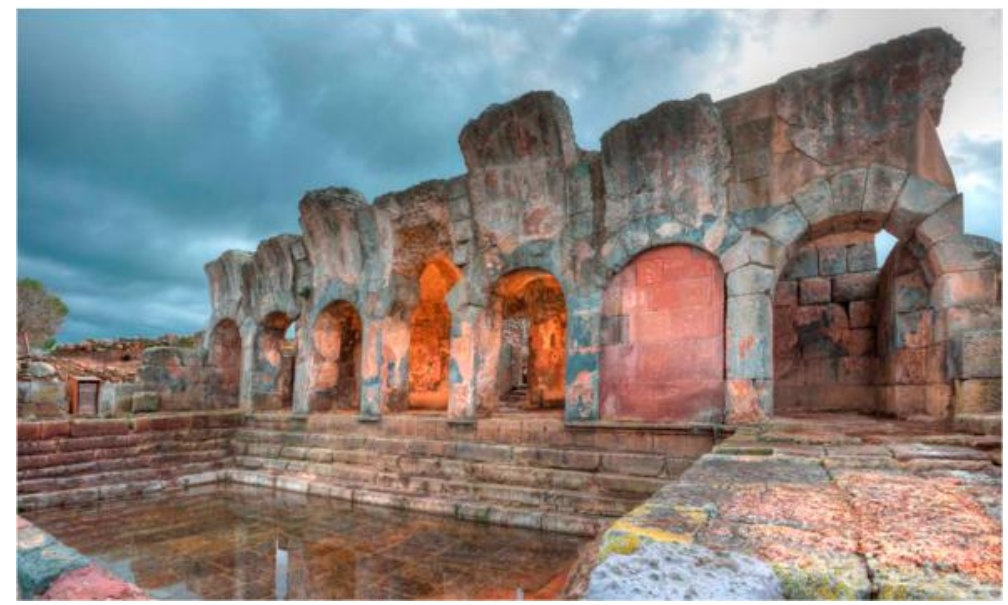

Figure 2. Forum Traiani, Ancient Roman thermal baths in Fordongianus (I-III centuries a.c).

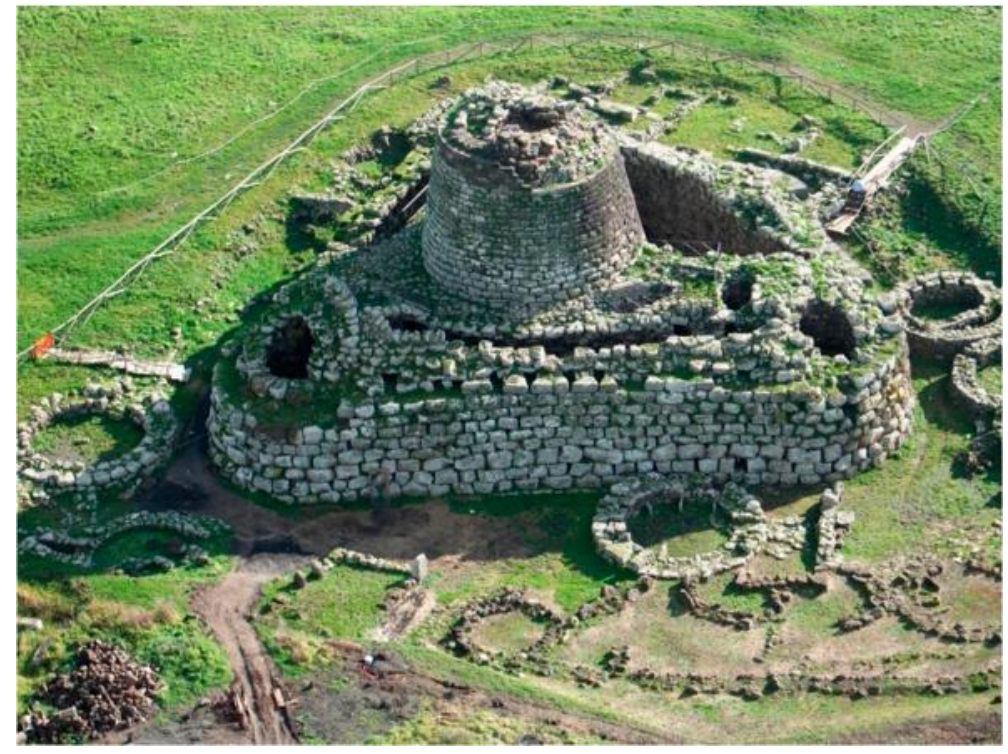

Figure 3. Santu Antine nuraghe, near Torralba (North-West Sardinia). It was built from 1800 to 1450 b.c.

Important examples of the use of these volcanic rocks, which are used in construction as well as by architects, can be typically seen in the civic center of several Sardinian towns: "Trachytes" are used to make different architectural parts in both public and private buildings, as ashlars, pillars, capitals, architraves, jambs, statues, friezes and etc. A special mention should be made of the many churches built in the 12th and 13th centuries, that can be considered a showcase where the visitor can observe the "trachytes" in all shapes and sizes; some examples are shown in Figure $4 \mathrm{a}-\mathrm{c}$. 


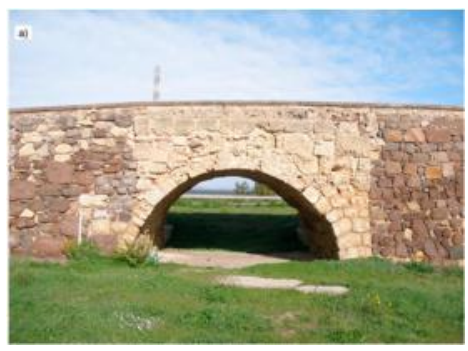

(a)

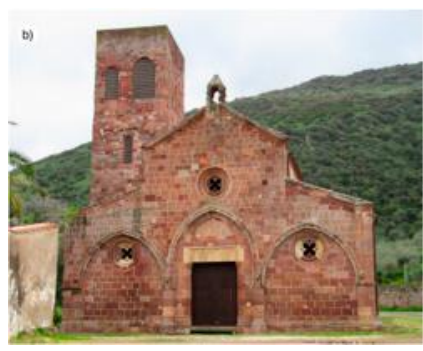

(b)

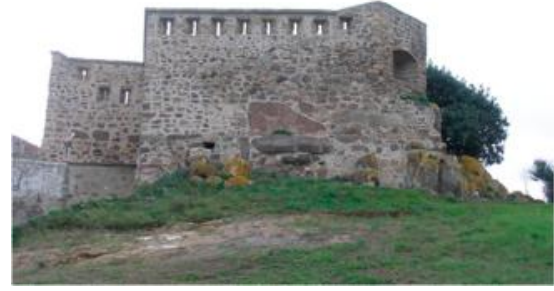

(c)

Figure 4. Ancient Roman bridge in Sant'Antioco (a). It was restored in 1858, 1893 and 1920; The Church of San Pietro extra muros in Bosa (north-west Sardinia, XI-XIII centuries) (b). It was built in Romanesque style by using various shades of pink and red rhyolites; (c) Fort Sabaudo, Sant'Antioco (built in 1813-1815).

The main areas where "trachytes" are currently quarried and processed are practically near to historic sites, which follow the geological distribution of outcrops. The main production facilities for both ornamental use and construction are located in Fordongianus (near Oristano) and Serrenti (Campidano) where the quarrying activity has started again about twenty years ago.

With regard to the latter, which is currently being reassessed, it is quarried to obtain the stone known as "Pietra di Serrenti", a light-grey pyroclastic andesite, which is easy to be carved and split; it has been quarried and processed by skilled stonemasons since the 19th century from the quarry of Monte Atzorcu and used to build the traditional portals of both Serrenti houses including the houses (Figure 5), the old market hall and the local Court of Justice in Cagliari (shown in Figure 6), a part of the portico of Via Roma, the churches of San Francesco (in Cagliari, too), squares, and an array of monuments all over Campidano, etc.

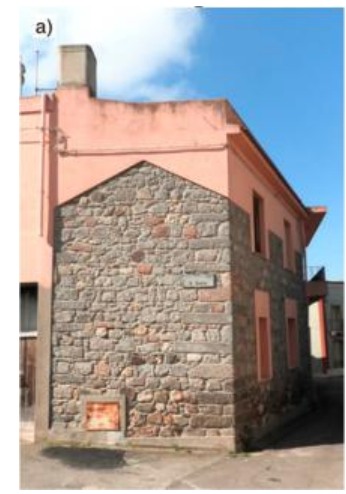

(a)

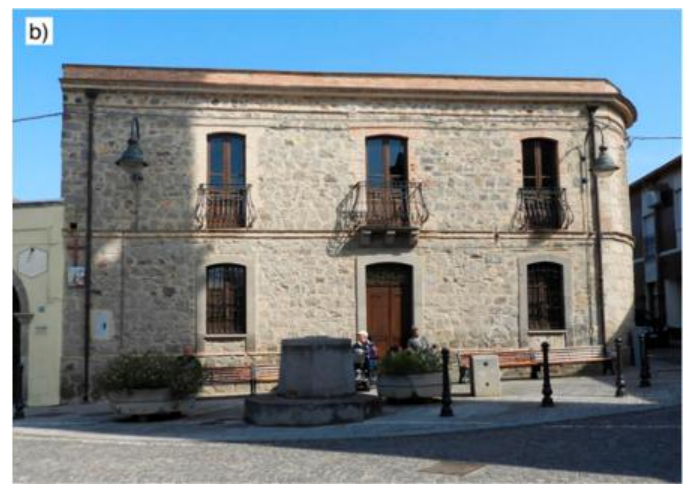

(b)

Figure 5. (a) and (b): two examples of houses, (a) and (b), built by using "Pietra di Serrenti".

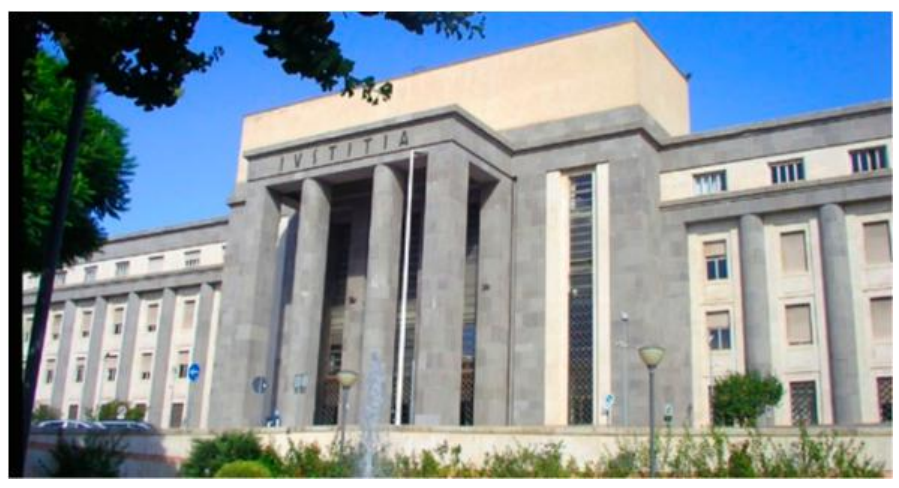

Figure 6. Court of Justice in Cagliari, built in 1938 by using also the "Pietra di Serrenti". 
It should be noted that all the different Sardinian "trachytes" started to be utilized at different moments throughout history. For example, Fordongianus "trachytes" have been used since Roman times and the Pietra di Serrenti since 19th century, while the use of Red Montresta in building is relatively recent.

\section{Geological Framework}

Figure 1 shows the lithological map of volcanics in Sardinia, which are related to two different volcanic cycles: A Plio-Pleistocenic one and a Oligo-Miocenic the second.

The first cycle occurred abundantly in the mid-western part of Sardinia and started when the island began to separate from the European continental mass during the Lower Oligocene. The subsequent opening of the Balearic basin activated a subduction zone to which the main phase of this volcanism is linked. This volcanic phase is composed of two main complexes both starting with mainly andesitic breccias and lavas, followed by more felsic product as tuff, lavas and ignimbrites. Most of these products are subaerial. However, during the rest of Miocene, a marine transgression with deposition of sediments as conglomerate, sandstone, clay and limestone covered most of these outcrop [8-11].

These volcanic activity can be shared in different phases:

- A first sequence from $32 \mathrm{My}$ : Outcrops in Central-West and South Sardinia, is characterized by lava with an intermediate to basic chemistry. These rocks generally present a dome structure, which is often associated with pyroclastic sediments.

- The second acid explosive from 23 My: Characterized by volcanic products essentially dacitic to rhyolitic, ignimbrites and subordinate lavas. This sequence outcrops in several parts of Central Sardinia.

- The third sequence goes from 19 to 16 Ma: Prevalent outcrops in Western, Central and Southern Sardinia. Here, volcanic rocks are composed by andesites and basalts that have been deposited by means of lava flows and pyroclastic sediments, both subaqueous and subaerial, or as lava domes and associated explosive phreatic-magmatic products.

- The last activity between 17 and $13 \mathrm{Ma}$ is characterized by ignimbritic, pyroclastic and lava-like rocks. These products are riolitic and dacitic (with rare episodes of pyroclastic sedimentation with sanidine), sometimes commenditic (Sulcis).

All these volcanic products have subalkaline affinity as shown in the Middlemost diagram of Figure 7. This diagram has been successfully, and often compared to the original definition of Middlemost [12], which reported only alkaline series [13].

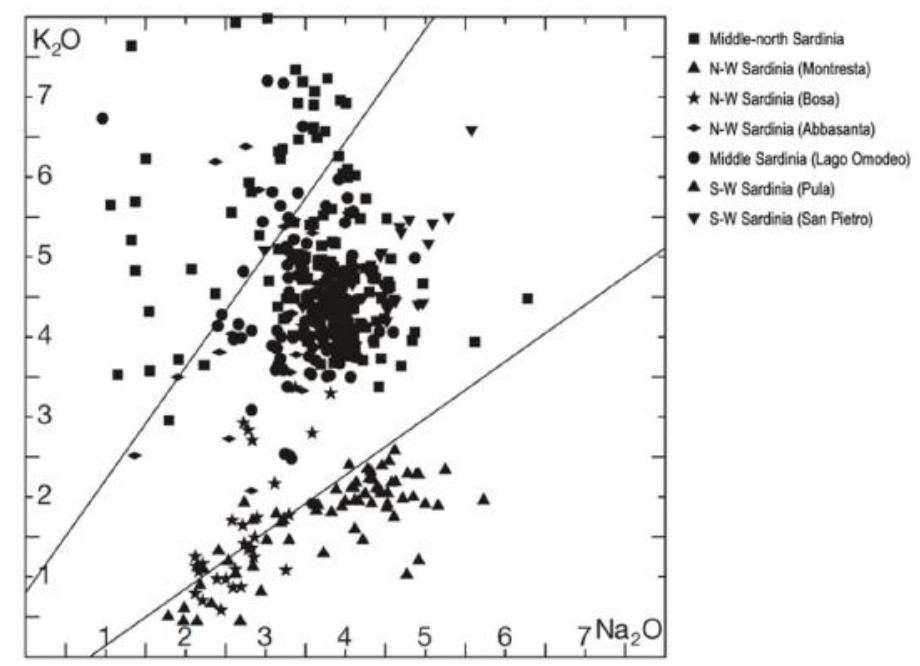

Figure 7. Middlemost (1975) summary diagram of all oligo-Miocene volcanics of Sardinia (elaborated by Columbu et al. [13]). 
In summary, dacitic to rhyolitic ignimbrites are the prevailing products of volcanic activity, followed by andesitic, basaltic andesitic and, finally, basaltic lavas [11].

Figure 8a-f shows the micro-photographies under crossed polars of six different Sardinian "trachytes"; their differences, explained in the figures caption, are clear.

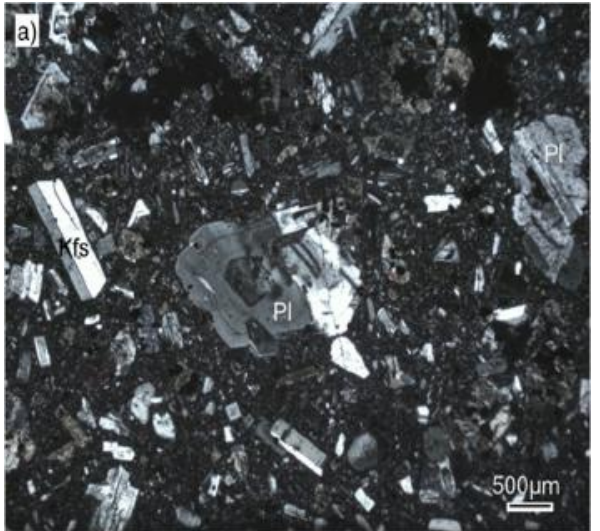

(a)

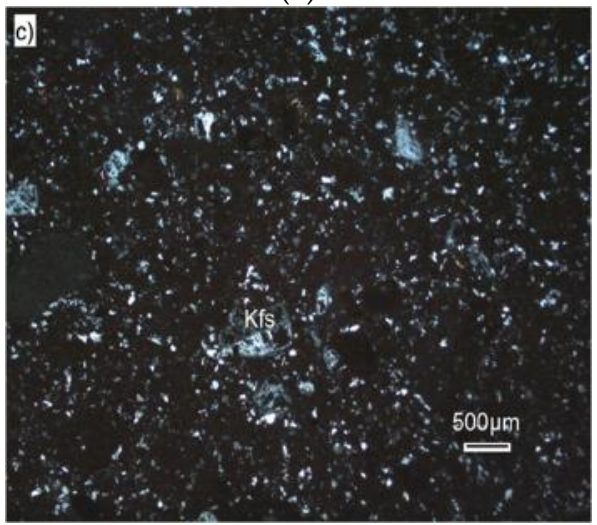

(c)

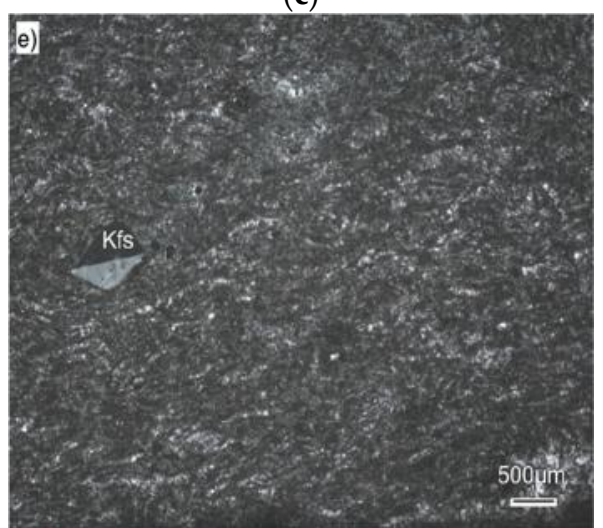

(e)

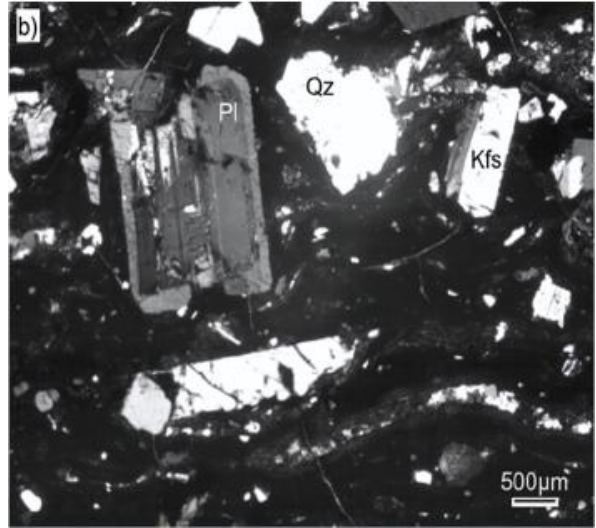

(b)

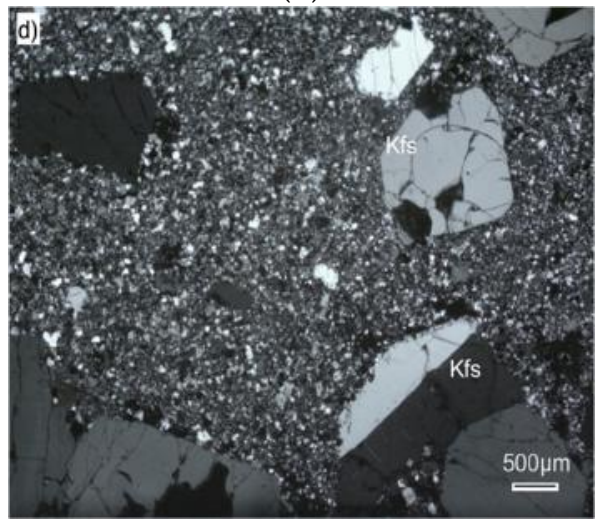

(d)

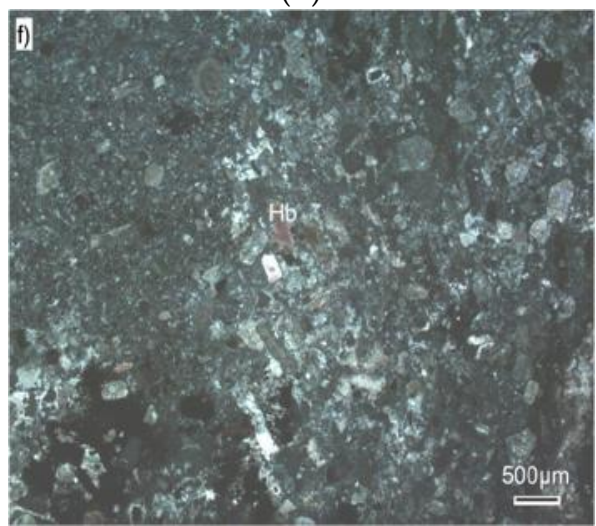

(f)

Figure 8. Thin section micro-photographies for some representative samples of Early Miocene volcanic rocks from Sardinia. The observed mineral phases are euhedral to subhedral K feldspar, plagioclase, quartz, horneblende in a groundmass from hypohyaline (Ploaghe (a), Sant'Antioco (b)) to hypocrystalline (Fordongianus red (c), Carloforte (d), Allai (e)) showing a porphyritic texture and different porphyric index. In the Serrenti area, the andesitic rocks, which include domes and volcaniclastic products, is interested by epithermal phenomena, so the outcrops are interested by propilitic alteration and silicification (f). Legend: $\mathrm{pl}=$ plagioclase; $\mathrm{Kfs}=$ alkali feldspar:sanidine; $\mathrm{qz}=$ quartz, $\mathrm{hb}=$ hornblende. 


\section{State of Art}

Pyroclastic rock are widely quarried in all the historical provinces of the Island, mainly in the areas of Fordongianus-Allai, Ottana, Sedilo, Ozieri and Serrenti as ornamental stone and building stone both as aggregates and ashlars.

The beauty of Sardinian "Trachyte" lies in its warms colors, whose intensity may vary even within a single quarry run, a single slab and therefore a single product, enhancing the unique character of this natural stone.

Color variability of Sardinian "trachytes" is neither a defect, nor a limit, but a very peculiar feature of this type of material that is skillfully used for building and ornamental purposes. It should be noted that the variability of color is extremely common; there are so many intermediate and softened shades amongst a vast range of colors [14].

According to the various genetic processes, appearance and texture may vary, not only from type to type, but even within the same commercial type. This is made possible by the orientation in which the quarryman makes the cuts, which can be enhanced, emphasized or minimized the role of constituents of each material (crystals, lithic fragments, veins etc.). A good example is provided by the "trachyte" Red Montresta, which looks very different depending on the direction of the cut (Figure 9a,b).

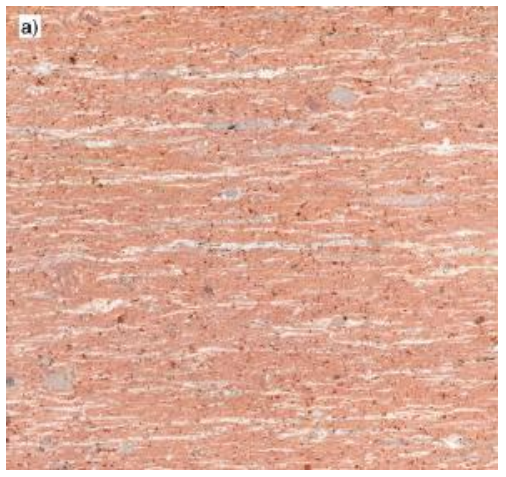

(a)

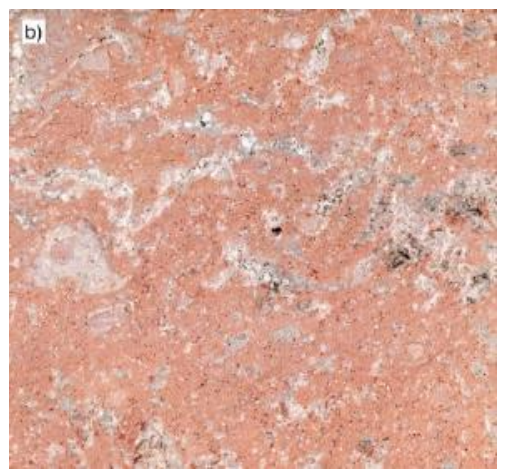

(b)

Figure 9. Appearances of "trachyte" Red Montresta: (a) Sample cut parallel to the flow planes, (b) sample cut orthogonal to the flow planes. Both the samples have a saw-plane surface.

The use of "trachyte" has its roots in ancient times, when it was used to make external paving, which has coupled to the use of cladding in contemporary times (as shown in Figure 10).

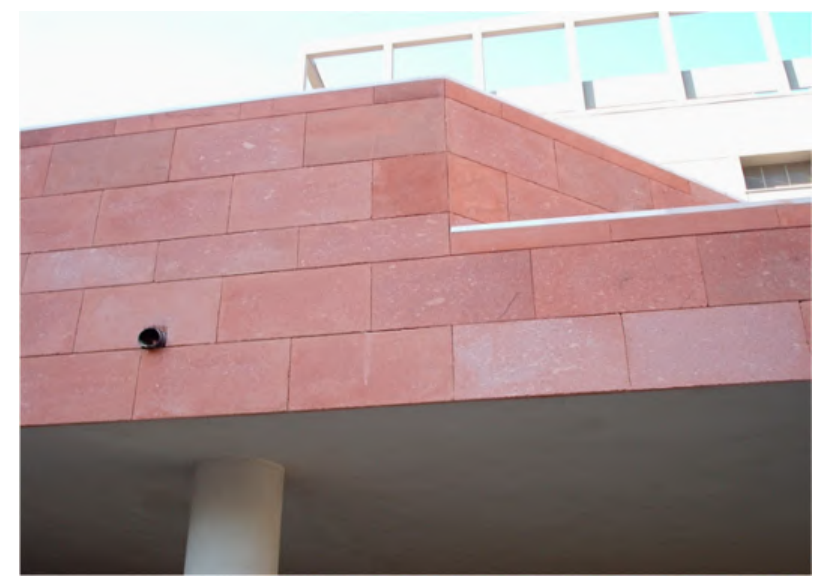

Figure 10. A detail of Teatro Massimo in Cagliari; the cladding, installed following a "run" pattern with runs in variable heights, was built using Fordongianus red "trachyte" (renewed in 2009). 
Using this pyroclastic rocks to build stairs best enhances the properties of various types; in fact, it is representative of all the various surface finishes that can be made, ranging from the mild thicknesses of the covered steps to the one of the solid steps in any shape (rectangular, triangular, fan-shaped, etc.) and any edge profiling.

Another important use is beautifully summed up both by celebratory and commemorative works of art, such as monuments and sculptures (Figure 11a,b), and by other works that are able to combine functionality, design and sensitivity for natural stone, as is the case with some fountains.

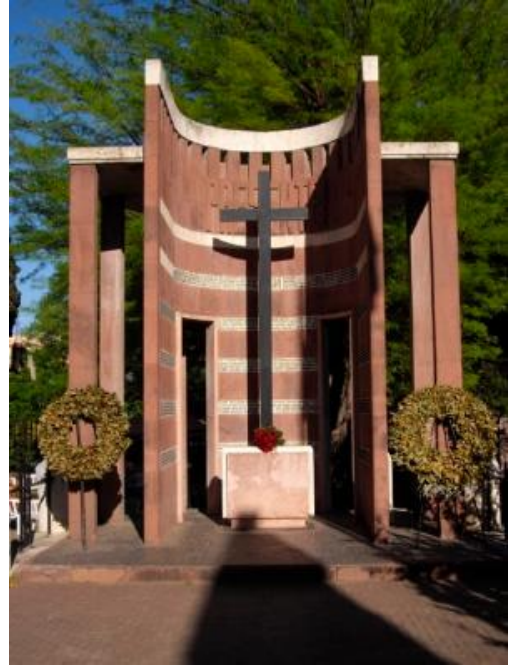

(a)

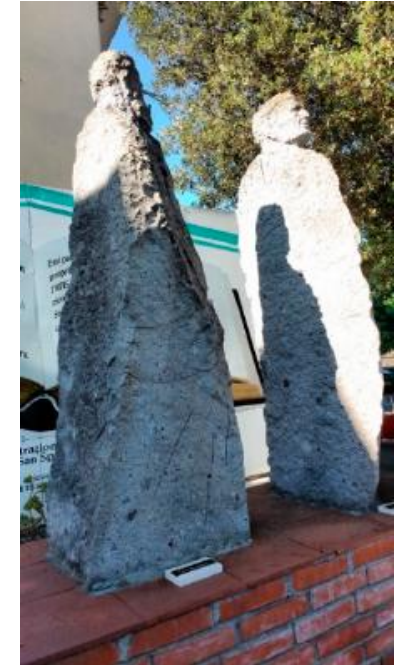

(b)

Figure 11. (a) Parco delle Rimembranze (Cagliari), the monument was built with Bosa red "trachyte"; (b) two sculptures in Pietra di Serrenti at San Sperate (Cagliari).

Sardinian "trachytes" are also used in a wide range of architectural components as arches, jambs, columns, pillars (Figure 12).
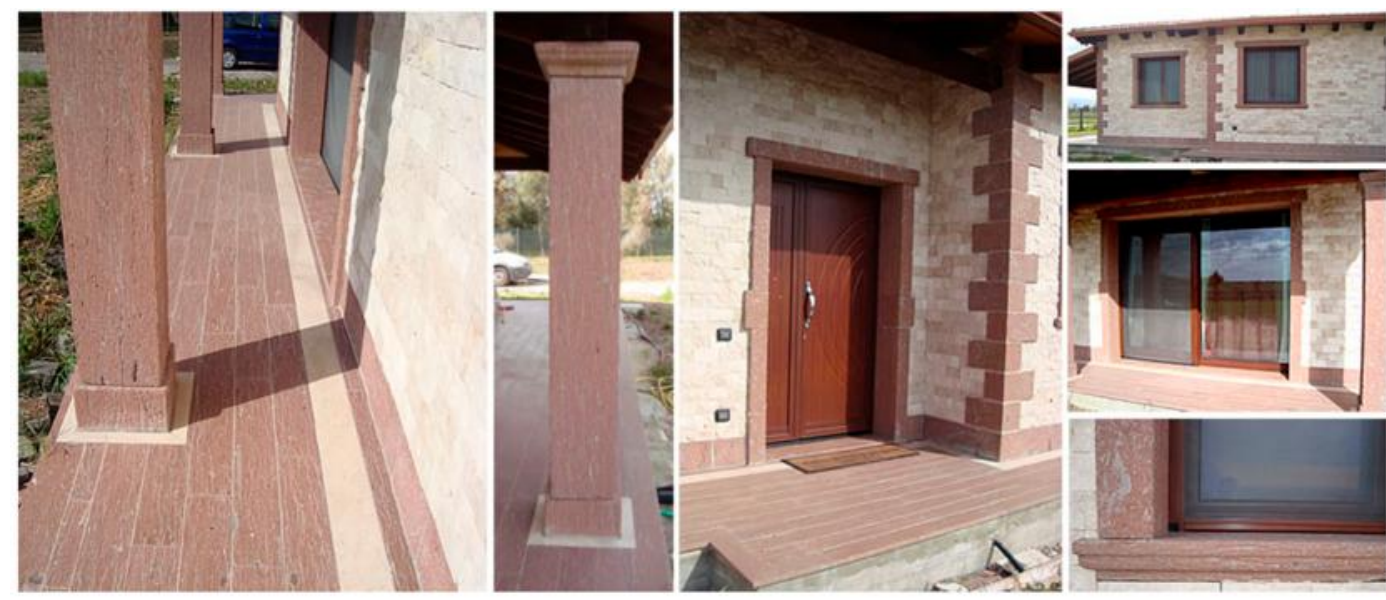

Figure 12. Some examples from a private building showing a combination of Red Montresta "trachyte" with Orosei marble (courtesy of Marmi \& Pietre I.C.S. s.r.l. [15]).

In recent years, production has proved to be particularly prolific in the segment of furnishing accessories, for which has supported the development of a whole range of interesting lines of production. It includes both objects with a strong aesthetic vocation, such as rose windows, cornices, inlay works, fretworks, etc., which combine aesthetics with functionality, such as clocks (wall, table), mirrors, tables of all sizes, fireplaces, bathroom sets, tops and elements for kitchens. 
Among the furnishing accessories, a new concept of mosaic was developed in bathroom fittings, kitchen countertops, tables, fountains and with stone elements.

Sardinian "trachytes" are often associated with other stones, including basalt and travertine, a material particularly appreciated by the antiqued finishing.

\subsection{Quarrying}

As stated above, the commercial name "Sardinian Trachyte" covers a wide variety of pyroclastic rocks that henceforth will all be referred to by their common trade name.

Currently, the Sardinian market offers a number of "trachyte" stone types, which come in different grains, hardness, compactness and colors (pink, red, yellow, gray, brown; less frequently, green-blue); Figure 13 shows some Sardinian "trachytes" which are important from an historical and commercial point of view. Moreover, as we look at Figure 13, it is interesting to see how geodiversity, regarded as the natural range (diversity) of geological rocks [16] and relative properties, is embedded in geoheritage.
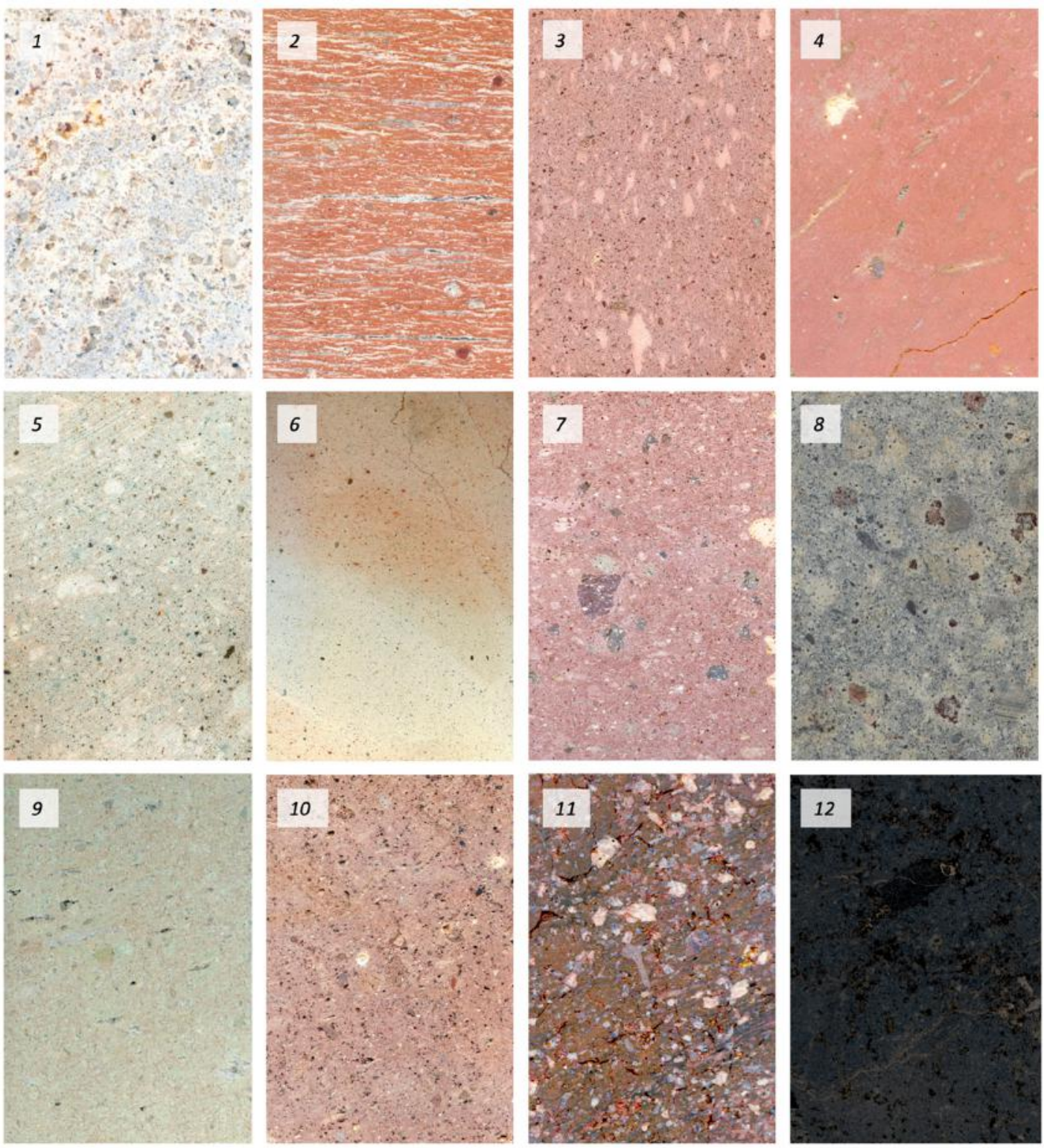

Figure 13. Some hystorical and commercial Sardinian "trachytes": 1) Carloforte, 2) Red Montresta, 3) Fordongianus red, 4) Allai, 5) Fordongianus green, 6) Ozieri, 7) Bosa, 8) Pietra di Serrenti, 9) Fordongianus gray, 10) Carbonia-Perdaxius, 11) Sant'Antioco, 12) Ploaghe. 
"Trachyte" is quarried and worked by companies located in the provinces of Oristano (Ardauli, Bosa, Fordongianus, Ruinas), Sassari (Benetutti, Ittiri, Oschiri, Ozieri, Uri), Cagliari (Serrenti, whose local quarry is shown in Figure 14), and Nuoro (Sedilo). Sardinian deposits are usually extensive and only slightly fractured, with exploitable depths ranging from 10 up to $65 \mathrm{~m}$ [17].

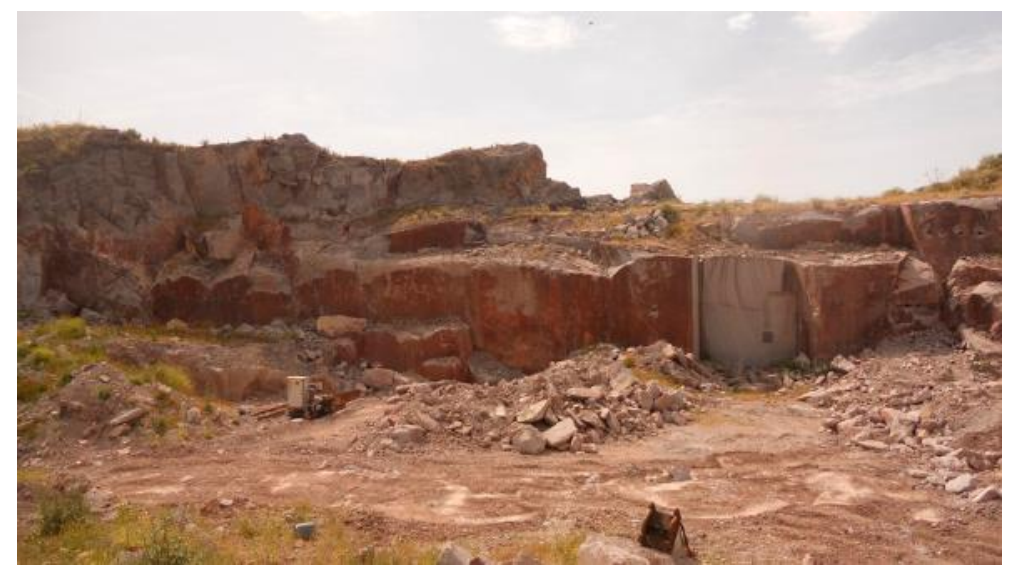

Figure 14. "Pietra di Serrenti" quarry in Monte Atzorcu.

The most common and effective quarrying method is by "single slice and horizontal step". Quarrying motion leads downward, using quarry cutters mounted on tracks and equipped with two toothed sawing disks-one vertically, and the other one horizontally. Cutting speed is about $1-2 \mathrm{~m} / \mathrm{min}$, with a maximum daily output of about $200 \mathrm{~m}^{2}$. After an adequate preparation of the quarry yard, parallel lines are traced on the surface of the rock slice with the vertical blade. The cut is then made simultaneously by the two blades: The vertical disk has a maximum cutting depth of $40 \mathrm{~cm}$, which determines the size of the primary blocks cut out of the quarry loaf (maximum size: $40 \times 60 \mathrm{~cm}$, and length according to requirements) as shown in Figure 15.

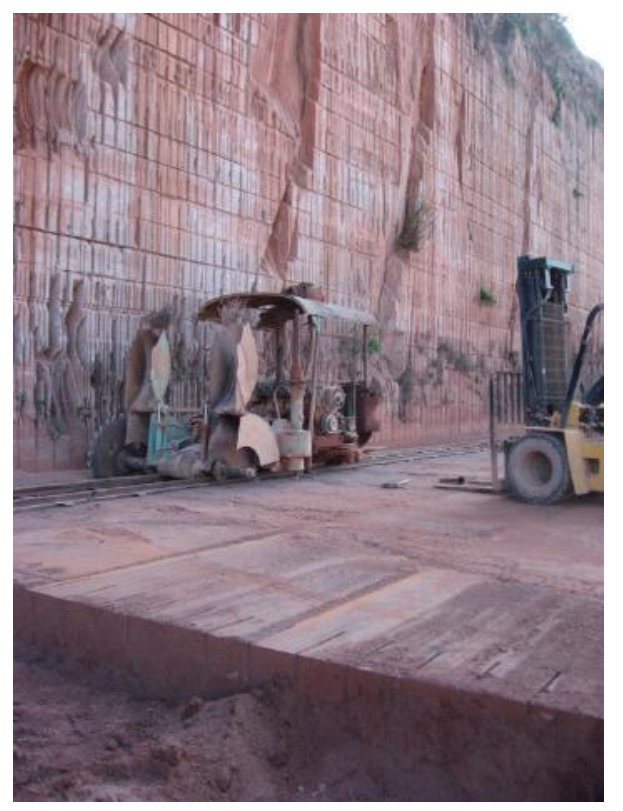

Figure 15. Partial view of a quarry of red "trachyte" excavated by using the "single slice and horizontal step" method (courtesy of Primavori, 2011).

Following this cutting method, other stone units as well as blocks can be obtained already during primary cutting in the quarry: Solid stone for masonry work, strips of different thicknesses, or slabs for 
paving applications. Strips and slabs can be obtained also in the fabrication plant, by cutting the block with a bridge sawing machine with diamond-tipped disk.

During the quarrying of larger blocks, a higher step is required. Its height should be at least equal to what will be the height of the quarried blocks; in this case, more advanced technologies such as chain-cutters and/or diamond-wire cutting machines have to be used (Figure 14).

Moreover, the stone deposit could have portions of rock of considerable volume which are already partially or completely detached from the rest of the rock mass; to isolate them, it is necessary to use earthmoving machines, such as shovels and excavators. The block is safely separated, perhaps with some drilling and metal wedges, and despite having irregular/non-geometric shapes, nevertheless provides significant volumes from which it is possible to produce large slabs dimensions, thicknesses and artifacts of complex shape.

\subsection{Stone-Processing and Products}

Similar to basalts [18], the processing of "trachytes" follows different techniques, depending on the quarry availability and the use of the stone material.

When dealing with a medium-large block, it is preferred to saw it into large slabs, obtained by means of diamond-wire plants, multi-blade gangsaw, giant disk cutters.

Some of the finishings that leave the surface smooth or semi-smooth, the saw-plane, the honed, the gloss and the antiqued are the more requested.

Bush-hammering, shot-blasting, brushing and splitting are the most popular surface finishings which have a more traditional rustic appeal.

Regarding the cut-to-size phase, this is carried out with modern CNC cutters, often equipped with devices that expand its performance and which can be used for profiling, shaping, lathes, and with traditional cutters (as jib mill or bridge milling).

The production of building elements, masonry blocks and brick-sized blocks represents a segment of particular importance for the "trachytes"; these are mainly parallelepiped-shaped artifacts, used during construction, and they are used as load-bearing elements in enclosure and containment walls, structural works and replacement restorations of architectural and artistic works, as shown in Figure 16.

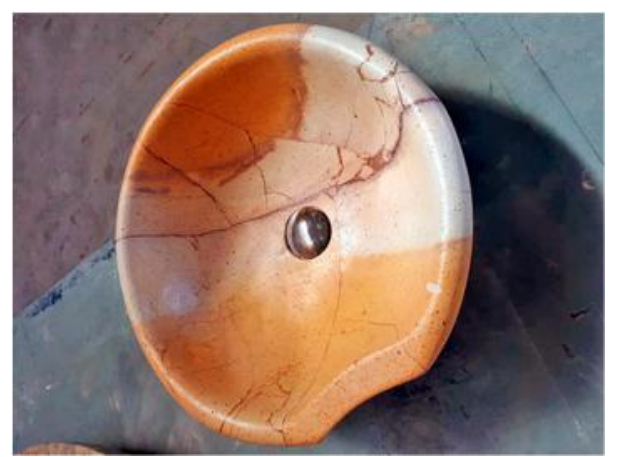

(a)

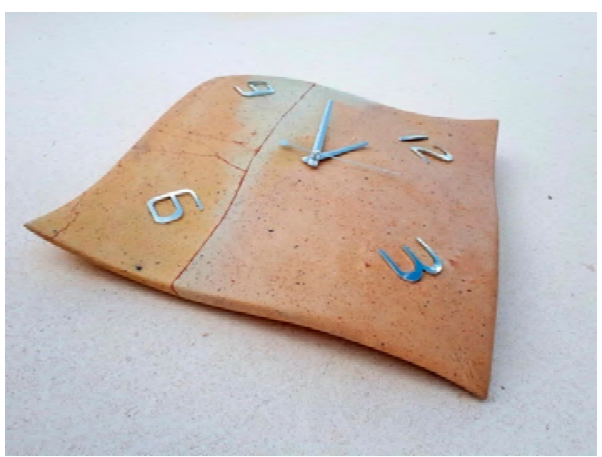

(b)

Figure 16. Sink (a) and clock (b) in Ozieri "trachyte" (courtesy of Pedra Noa di Gavino Mulas [19]).

\subsection{Notes on the Wheatering of Sardinian Volcanic Calkaline Rocks}

The different mineral composition (with some presence of glass, and some of different phenocrysts), a wide range of physical structure (due mainly to the porosity, density, hardness which are summarized in Table 1), can encourage the process of decay. In fact, the decay of stone depends on the combined action of weathering (e.g., solar radiation, rainwater, stream water, carbon dioxide, sulfate, seawater, dust etc.) and on its mineral composition, texture and structure of stone that is used in monuments and engineering structures. In particular, the weathering of volcanic rocks is mainly due to the combined 
action of the wind with sea salt spray in Sardinia. For example, in the facies with porphiric structure and high capillary porosity (i.e., "trachytes" of Fordongianus), salt from the seawater produces new crystal growths and salt accumulation in the pore, extensive efflorescence and subefflorescence, with consequent crumbling, flaking, detached crust, color change phenomena. On the contrary, in the well compacted ignimbrites and tuffs facies, that are characterized by very low porosity and permeability (as "trachyte" of Sant'Antioco) the wheatering is very weak and no changes are visible and the stones used are very resistant to the action of atmospheric agent.

Table 1. Physical and mechanical properties of some Sardinian trachytes currently on the market.

\begin{tabular}{|c|c|c|c|c|}
\hline $\begin{array}{l}\text { Stone Properties-UE } \\
\text { STANDARDS }\end{array}$ & UNIT & Pietra di Serrenti & Red Montresta & $\begin{array}{l}\text { Fordongianus } \\
\text { "Trachyte" }\end{array}$ \\
\hline $\begin{array}{l}\text { Petrographic denomination-EN } \\
\text { 12407:2007 }\end{array}$ & & Pyroclastic rock & Ignimbrite & Pyroclastic rock \\
\hline Real density_EN 1936:2007 & $\mathrm{kg} / \mathrm{m}^{3}$ & 2,204 & 2290 & 1612 \\
\hline Apparent density_EN 1936:2007 & $\mathrm{kg} / \mathrm{m}^{3}$ & 2,688 & n.a. & 2662 \\
\hline Total porosity-EN 1936:2007 & $\%$ & 18.00 & n.a. & 39.40 \\
\hline Open porosity_EN 1936:2007 & $\%$ & 17.00 & n.a. & 39.20 \\
\hline $\begin{array}{l}\text { Water absorption at atmospheric } \\
\text { pressure-EN 13755:2008 }\end{array}$ & $\%$ & 6.30 & n.a. & 21.70 \\
\hline $\begin{array}{l}\text { Water absorption coefficient by } \\
\text { capillarity EN 1925:2000 }\end{array}$ & $\mathrm{g} / \mathrm{m}^{2} \mathrm{~s}^{0.5}$ & 23.30 & n.a. & n.a. \\
\hline $\begin{array}{l}\text { Flexural strength under } \\
\text { concentrated load-EN } \\
\text { 12372:2007 }\end{array}$ & $\mathrm{MPa}$ & 18.90 & $\begin{array}{c}\text { 5.4-12.31 (dry } \\
\text { sample) } \\
1.63-6.871 \text { (wet } \\
\text { sample) }\end{array}$ & 8.20 \\
\hline $\begin{array}{l}\text { Flexural strength under } \\
\text { concentrated load (after } 48 \\
\text { freeze-thaw cycles)-EN } \\
\text { 12372:2007 + EN 12371:2003 }\end{array}$ & $\mathrm{MPa}$ & 15.50 & n.a. & not frost-resistant \\
\hline $\begin{array}{l}\text { Compressive strength-EN } \\
\text { 1926:2007 }\end{array}$ & $\mathrm{MPa}$ & 93.00 & $\begin{array}{l}\text { 93.2-104.51 (dry } \\
\text { sample) } \\
67.7-74.91 \text { (wet } \\
\text { sample) }\end{array}$ & 49.00 \\
\hline $\begin{array}{l}\text { Compressive strength (after } 48 \\
\text { freeze-thaw cycles)-EN } \\
\text { 1926:2007 + EN 12371:2003 }\end{array}$ & $\mathrm{MPa}$ & 90.10 & n.a. & 34.00 \\
\hline $\begin{array}{l}\text { Resistance to ageing by thermal } \\
\text { shock-EN 14066:2004 }\end{array}$ & $\%$ & n.a. & n.a. & $\Delta \mathrm{E}=-7.9$ \\
\hline $\begin{array}{l}\text { Abrasion resistance-EN } \\
\text { 14157:2005 }\end{array}$ & $\mathrm{mm}$ & 25 & $\begin{array}{l}1.75-1.871 \text { (dry } \\
\text { sample) } \\
1.91-2.041 \text { (wet } \\
\text { sample) }\end{array}$ & 23.00 \\
\hline $\begin{array}{l}\text { Resistance to ageing by SO2 action } \\
\text { in the presence of humidity-EN } \\
\text { 13919:2004 }\end{array}$ & $\%$ & $\begin{array}{c}\Delta \mathrm{m}=-0.94 \\
\text { significant } \\
\text { variation of the } \\
\text { color }\end{array}$ & n.a. & n.a. \\
\hline $\begin{array}{l}\text { Slip resistance by means of the } \\
\text { pendulum tester-EN 14231:2004 }\end{array}$ & & $\begin{array}{l}77 \text { (sawplane, } \\
\text { wet sample) }\end{array}$ & n.a. & $\begin{array}{c}76 \text { (sawplane, dry } \\
\text { sample) } \\
63 \text { (sawplane, wet } \\
\text { sample) }\end{array}$ \\
\hline $\begin{array}{l}\text { Linear thermal expansion } \\
\text { coefficient-EN 14581:2005 }\end{array}$ & $\mu \mathrm{m} / \mathrm{m} /{ }^{\circ} \mathrm{C}$ & n.a. & n.a. & 5.94 \\
\hline Rupture energy EN 14158:2005 & $\mathrm{J}$ & 8 & n.a. & n.a. \\
\hline $\begin{array}{l}\text { Breaking load at dowel hole-EN } \\
\text { 13364:2003 }\end{array}$ & $\begin{array}{l}\mathrm{mm}\left(\mathrm{d}_{1}, \mathrm{~b}_{\mathrm{A}}\right) \\
\mathrm{kN}(\mathrm{F})\end{array}$ & $\begin{array}{l}\mathrm{d}_{1}=11 \\
\mathrm{~b}_{\mathrm{A}}=49 \\
\mathrm{~F}=1.50\end{array}$ & n.a. & $\begin{array}{l}\mathrm{d}_{1}=11,1 \\
\mathrm{~b}_{\mathrm{A}}=37 \\
\mathrm{~F}=0.86\end{array}$ \\
\hline
\end{tabular}




\subsection{Market}

Unlike marble and granite, whose market trend is widely documented, "trachytes" quarrying (raw production) can be difficult to track down and describe [20]. In fact, the quarried "trachytes" is often sold locally, in other words it doesn't cross the boundaries of the country where it was quarried and processed; this is due to the low market value when compared to more noble varieties of marbles and granites [21]. However, a little percentage of Sardinian "trachyte" is currently exported to Europe, especially to Germany and UK, and also to the USA. Some is exported from Sardinia to the Italian domestic market.

Statistics are shown in Table 2 and Figure 17; in Table 2, the production trend of Sardinian "trachytes and tuffs" for ornamental use is upward. Figure 16 shows the number of active quarries during the last 25 years.

Table 2. Sardinian "trachytes" and tuffs (used as ornamental stone) official quarrying production in 1994-2017 (in $\mathrm{m}^{3}$ ). Elaboration from Regione Autonoma della Sardegna (R.A.S.) [22] and our own data [23,24].

\begin{tabular}{cccccccc}
\hline & $\mathbf{1 9 9 4}$ & $\mathbf{1 9 9 9}$ & $\mathbf{2 0 0 2}$ & $\mathbf{2 0 0 5}$ & $\mathbf{2 0 0 7}$ & $\mathbf{2 0 1 2}$ & $\mathbf{2 0 1 4 - 2 0 1 7}$ \\
\hline Quarrying Production $\left[\mathbf{m}^{3}\right]$ & 21,300 & 5240 & 13,195 & 19,950 & 12,013 & 15,900 & 111,685 \\
\hline
\end{tabular}

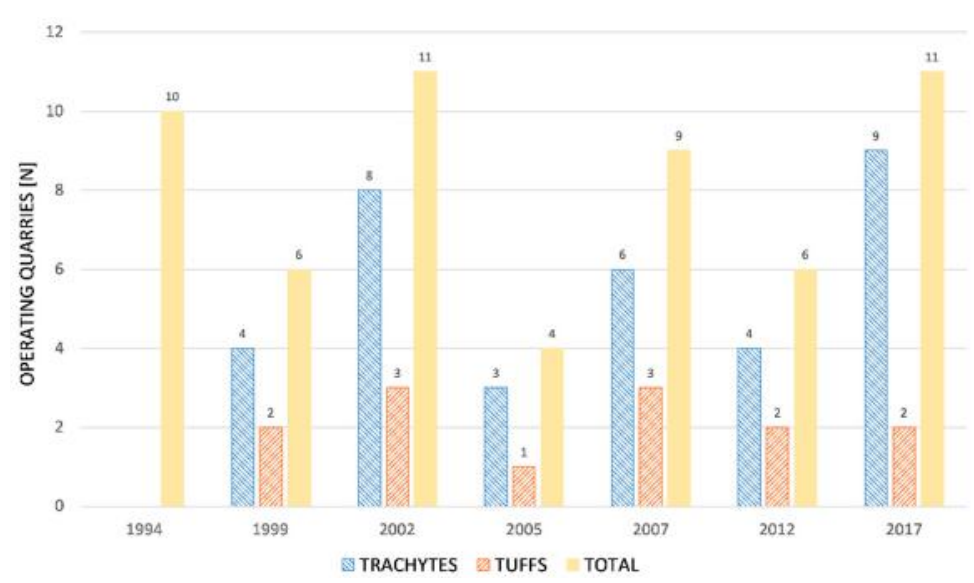

Figure 17. Number of "trachytes" and tuffs operating quarries in Sardinia. Elaboration from R.A.S. [22] and our own data $[23,24]$.

It has been difficult to evaluate the productions before 1999 because "trachytes" and tuffs had been inserted in the group "stones", which included also sandstones and basalts in the previous statistics.

\section{Geotourism Remarks}

Geoethical values promote the right of citizens to access and receive transparent information pertaining to the intrinsic nature and meaning of geodiversity $[25,26]$. Geoheritage encourages the knowledge of the notions pertaining to the preservation of Earth Science principles [27].

We believe that the best way to represent geoethical values and geoheritage is the organization of a tour of historical towns and archaeological sites where Sardinian different types of "trachyte" have been used. This info-tour should be followed by the visit to historical quarries of "trachytes" as well as those quarries which are still fully operational. The tours will be led by qualified scientific guides with a degree in geoheritage topics.

\section{A Possible Example: Bosa Heritage Stone Tour}

Bosa is a municipality built from a medieval town on the western coast of Sardinia (see Figure 1). This municipality received a tourism award as Italy's second most attractive town in 2014 (tourism 
award 'I borghi più belli d'Italia' [28]). Our proposal consists of a walking tour to view a number of monuments which were built using the local Bosa "Trachyte" (Figure 13(7)) such as the castle of Serravalle-i.e., a XIII century fortification that dominates the town of Bosa from above-and the Church of San Pietro extra muros (already shown in Figure $4 \mathrm{~b}$ ). The tour shall end at the historical quarry "sas Pedraggias". It shall consist of about $6 \mathrm{~km}$ and last for about 4 hours. For the above mentioned sites, see Figure 18.

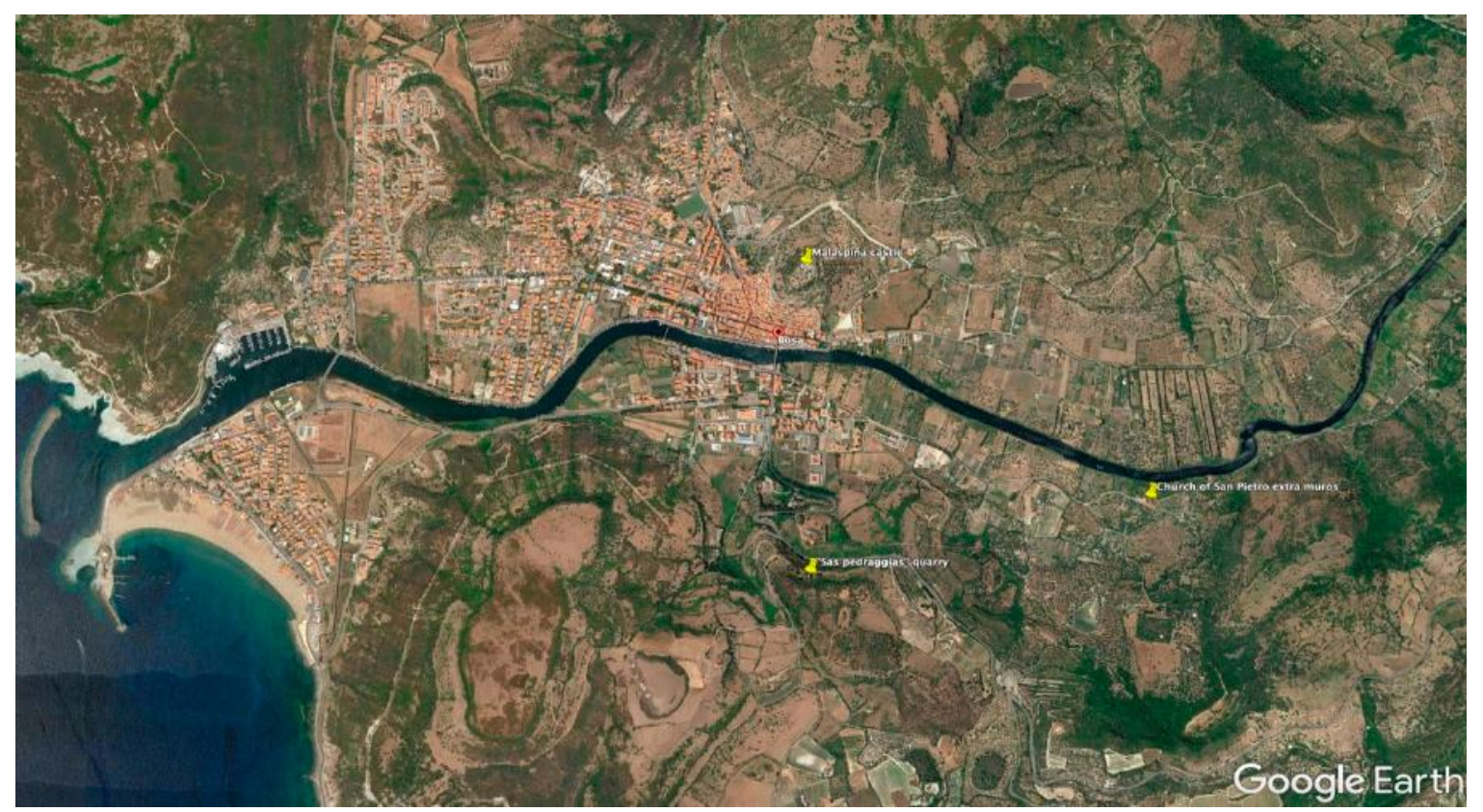

Figure 18. Aerial view of Bosa and location of principal monuments and historical "trachyte" quarry for the hypothetical Bosa heritage stone tour (from Google Earth).

\section{Conclusions}

Sardinian pyroclastic rocks, which are generally called Sardinian "trachytes" are stones which are widespread in the western part of Sardinia: These kinds of stone were used to build a lot of works that have featured the Island's history, from its prehistory (as witnessed by "domus de janas" and nuraghi), to the modern age, via the Roman and medieval ages.

During the last twenty years, the use of Sardinian "trachytes" has increased due not only to fashion, but also for the restoration of a high number of civic centers in several municipalities throughout the island.

Using commodity-related terms, Sardinian "trachyte" can show different colors from the pale yellow to the red through to pinkish, the green and the dark grey and has different mechanical characteristics. It is a fairly cohesive rock and shows remarkable elements of aesthetic value that have favored, its popularity as a building resource and ornamental stone in Sardinia.

At present, Sardinian "trachyte" is very much demanded for its compactness, homogeneity, color and because of its easy workability; it is usually utilized for flooring, covering, blocks for open-face constructions and buildings as well as for architectural and street furnishing elements. All this is highlighted by the growing production in the island.

Exactly for the above-mentioned reasons, it is necessary to raise awareness of people about the diversity, the history and use of Sardinian "trachytes" through guided tours.

Author Contributions: Conceptualization, N.C.; investigation, S.M.G.; resources, N.C. and S.M.G.; data curation, N.C.; writing—original draft preparation, N.C. and S.M.G.; supervision, N.C.; funding acquisition, N.C.

Funding: This research received no external funding.

Acknowledgments: The Authors wish thank to Antonio Dessena for his support in the cartographic elaboration. 
Conflicts of Interest: The authors declare no conflict of interest.

\section{References}

1. Grillo, S.; Mocci, S.; Pia, G.; Spanu, N.; Tuveri, L. Il Manuale Tematico Della Pietra; Sanna, U., Atzeni, C., Eds.; Itaca (pub.): Fiumicino, Italy, 2009; pp. 20-34. (In Italian)

2. Carmignani, L.; Oggiano, G.; Barca, S.; Conti, P.; Salvadori, I.; Eltrudis, A.; Funedda, A.; Pasci, S. Note illustrative della Carta Geologica della Sardegna a scala 1:200.000. In Memorie Descrittive della Carta Geologica d'Italia; Servizio Geologico d'Italia, Ed.; ISPRA: Roma, Italy, 2001; Volume 60, 283p.

3. Cooper, B.J.; Marker, B.; Pereira, D.; Schouenborg, B. Establishment of the "Heritage Stone Task Group" (HSTG). Episodes 2013, 36, 8-10.

4. Pereira, D.; Baltuille, J.M. Documenting natural stone to preserve our cultural and architectonic heritage. Materiales de Construcción 2014, 64, 002.

5. Cooper, B.J. Towards establishing a "Global Heritage Stone Resource" designation. Episodes 2010, 33, $38-41$.

6. Brocx, M.; Semeniuk, V. Geoheritage and geoconservation-History, definition, scope and scale. J. R. Soc. West. Aust. 2007, 90, 53-87.

7. Argiolas, S.; Carcangiu, G.; Floris, D.; Massidda, L.; Meloni, P.; Vernier, A. Le piroclastiti dell'antica Forum Traiani (Fordongianus)—Sardegna centrale: caratterizzazione, tecniche di estrazione e specificità di utilizzo nei secoli. In Proceedings of the Atti Conv. "Le Risorse Lapidee Dall'antichità a Oggi in Area Mediterranea", Canosa di Puglia, Italy, 25-27 September 2006; pp. 33-38. (In Italian).

8. Coulon, C. Le Volcanisme Calco-Alcalin Cénozoique de Sardaigne (Italie). Petrographie, Gèochimie et Genèse des Lavas Andèsitiques et des Ignimbrites. Ph.D. Thesis, Université St Jerome, Aix Marseille, France, 1977.

9. Conte, A.M. Petrology and geochemistry of Tertiary calcalkaline magmatic rocks from the Sarroch district (Sardinia, Italy). Periodico di Mineralogia 1997, 66, 63-100.

10. Lustrino, M.; Morra, V.; Melluso, L.; Brotzu, P.; d'Amelio, F.; Fedele, L.; Franciosi, L.; Lonis, R.; Petteruti Liebercknecht, A.M. The Cenozoic igneous activity of Sardinia. Periodico di Mineralogia 2004, 73, 105-134.

11. Guarino, V.; Fedele, L.; Franciosi, L.; Lonis, R.; Lustrino, M.; Marrazzo, M.; Melluso, M.; Morra, V.; Rocco, I.; Ronga, F. Mineral compositions and magmatic evolution of the calcalkaline rocks of northwestern Sardinia, Italy. Periodico di Mineralogia 2011, 80, 517-545.

12. Middlemost, E.A.K. The basalt clan. Earth Sci. Rev. 1975, 11, 337-364. [CrossRef]

13. Carboni, D.; Columbu, S.; Corazza, G.; Garau, A.M.; Ginesu, S.; Macciotta, G.; Marchi, M.; Marini, C. Manuale Sui Materiali Lapidei Vulcanici Della Sardegna Centrale e Dei Loro Principali Impieghi Nel Costruito; Tipografia Ghilarzese, Ed.; ISKRA: Ghilarza, Italy, 2011; p. 193. (In Italian)

14. Primavori, P. I materiali Lapidei della Sardegna. In Sardegna Ricerche; Regione Autonoma della Sardegna, Ed.; Sainas Industrie Grafiche: Villaspeciosa, Italy, 2011; pp. 261-307. (In Italian)

15. Marmi \& Pietre I.C.S. s.r.l. Available online: www.marmiepietrevinci.it/index.htm (accessed on 10 June 2019).

16. Gray, M. Geodiversity: Valuing and Conserving Abiotic Nature, 2nd ed.; John Wiley \& Sons: Chichester, UK, 2013.

17. Massacci, G.; Medici, G. Le piroclastiti Sarde come pietre ornamentali. In Proceedings of the Atti Del Convegno “Le Materie Prime Minerali Sarde”, Cagliari, Italy, 23-24 Giugno 1997; Marini, C., Ed.; CUEC pub.: Cagliari, Italy, 1997. (In Italian)

18. Careddu, N.; Grillo, S.M. Sardinian Basalt_An Ancient Georesource Still En Vogue. Geoheritage 2019, 11, 33-45. [CrossRef]

19. Pedra Noa di Gavino Mulas. Available online: www.pedranoa.com/index.php (accessed on 10 June 2019).

20. Careddu, N.; Siotto, G.; Marras, G. The crisis of granite and the success of marble: Errors and market strategies. The Sardinian case. Resour. Policy 2017, 52, 273-276. [CrossRef]

21. Montani, C. XXIX Report Marble and Stones in the World 2018; Aldus: Carrara, Italy, 2018.

22. R.A.S, 2007. - Piano Regionale delle Attività Estrattive (PRAE). Regione Autonoma della Sardegna, ottobre 2007. Available online: http://www.regione.sardegna.it/speciali/pianoattivitaestrattive/ (accessed on 5 July 2019).

23. Careddu, N.; Scanu, M.; Desogus, P. (Eds.) Map of Natural Stones from Sardinia; Miniere di Sardegna: Cagliari, Italy, 2015.

24. Careddu, N.; Scanu, M.; Desogus, P. Notes on the poster "Map of natural stones from Sardinia (Italy)". Key Eng. Mater. 2019, accepted. 
25. Ferrero, E.; Giardino, M.; Lozar, F.; Giordano, E.; Belluso, E.; Perotti, L. Geodiversity action plans for the enhancement of geoheritage in the Piemonte region (north-western Italy). Ann. Geophys. 2012, 55, 487-495.

26. Careddu, N.; Di Capua, G.; Siotto, G. Dimension Stone Industry should meet the fundamental values of Geoethics. Resour. Policy 2019. accepted.

27. Doyle, P.; Easterbrook, G.; Reid, E.; Skipsey, E.; Wilson, C. Earth Heritage Conservation; The Geological Society in Association with Open University: London, UK; City Print (Milton Keynes) Ltd.: Milton Keynes, UK, 1994.

28. Bosa è il secondo borgo più bello d'Italia. La Nuova Sardegna. Available online: http://www.lanuovasardegna. it/oristano/cronaca/2014/04/21/news/bosa-e-il-secondo-borgo-piu-bello-d-italia-1.9087617 (accessed on 2 July 2019).

(C) 2019 by the authors. Licensee MDPI, Basel, Switzerland. This article is an open access article distributed under the terms and conditions of the Creative Commons Attribution (CC BY) license (http://creativecommons.org/licenses/by/4.0/). 